\title{
Power: An Example of Its Changing Nature
}

\section{RUTH REES}

Queen's University

\section{ABSTRACT}

The purpose of the paper is to describe some experiences of a female Associate Dean in a university faculty in terms of the Marshall (1984) typology of power to reveal its changing nature - evolving from a traditional perspective of having power over others towards one of a "web of relations" (Burbules, 1986). The typology, broadened through the literature review, contains five components of power: power over others, a traditional perspective; structural factors; power through others or facilitative power; power with others or empowerment; and personal power. The experiences of the author reveal that she sees herself as having little power over others and having many aspects of personal power. This finding is similar to two previous studies with women as managers (Adler, Laney, \& Packer, 1993; Millers \& Cummins, 1992). However, the author self-reflects that most of her power is facilitative power, although she believes that the ideal form we should strive for in the university would be empowerment, where the leader is the web builder so that others can be creating and generating power.

\section{RÉSUMÉ}

Le but de cet article est de décrire quelques expériences faites par une vice-doyenne dans une Faculté universitaire. La typologie de Marshall (1984) a été utilisée comme révélateur du pouvoir sous ses formes diverses et mouvantes qui évoluent de la perspective 
traditionnelle de l'ascendant qu'on développe sur d'autres à celle d'un «réseau de relations» (Burbules, 1986). Cette perspective typologique est approfondie grâce à une recension. On y retrouve cinq composantes du pouvoir: le pouvoir sur autrui (perspective traditionnelle); les facteurs structuraux; le pouvoir par les autres, facilitateur; le pouvoir avec les autres, ou appropriation; et le pouvoir personnel. Les expériences de l'auteure révèlent qu'elle ne se reconnaît que peu de pouvoir sur les autres et qu'elle témoigne en revanche de bien des aspects du pouvoir personnel. Ce résultat s'accorde à celui de deux études antérieures auprès de femmes managers (Adler, Laney \& Packer, 1993; Millers \& Cummins, 1992). Cependant, l'auteure approfondit sa réflexion en posant que la plus grande part de son pouvoir joue un rôle facilitateur, et ceci bien que ses convictions l'inclinent à opter, en milieu universitaire, pour un idéal de l'appropriation dans lequel le leader serait un créateur de réseaux de façon à ce que d'autres puissent développer du pouvoir.

Far into the night, while the other creatures slept, Charlotte worked on her web. First she ripped out a few of the orb lines near the center. She left the radial lines alone, as they were needed for support. As she worked, her eight legs were a great help to her. So were her teeth. She loved to weave, and she was an expert at it.

\section{Charlotte's Web by E.B. White}

This article describes power as experienced by a woman university administrator. Specifically, Marshall's (1984) typology of power is reviewed and then compared with the author's first-hand leadership experiences. That analysis reveals the changing nature of power - evolving from a traditional perspective of having power over others towards one of a "web of relations" (Burbules, 1986), an intricate network of sharing, encouraging and creating power within and among others.

Distinctions between male and female leadership have emerged in the literature (e.g., Helgesen, 1990; Kanter, 1977). Those distinctions are slow in coming however, possibly because the number of women in senior level positions within all types of organizations is small (Aisenberg \& Harrington, 1986; Blackmore, 1989; Caplan, 1993; and Epstein, 1971). Even in the education profession where women represent the majority of employees $(60 \%)$, the number of women in management/ administrative positions is only 25\% (Statistics Canada, 1992). 
What is even more disconcerting is that women's involvement in formal positions of leadership drops off sharply as one moves through the school system - from elementary through to secondary school and then into postsecondary institutions. While women constitute about $35 \%$ of the elementary school principalship, women comprise about $10 \%$ of the secondary school principalship in Canada (Rees, 1990); and to date, only eight of eighty-nine Canadian universities and affiliates (or 9\%) have women as their chief executive officers (Canadian Education Association, 1997).

Despite their small numbers, women in the university system can be found in administrative positions, albeit more often in middle management (Caplan, 1993; Chamberlain, 1988). In 1991-92, the Council of Ontario Universities reported that women occupied $46.2 \%$ of middle management positions but only $19.2 \%$ of upper management positions in Ontario universities (Caplan, 1993). While women are on many committees and are often found as directors of student affairs (Chamberlain, 1988), they are "rarely made department heads, deans or other top administrators . . or are on funding bodies or editorial boards" (Caplan, 1993, p. 180).

Women are not the majority in positions of senior management within the professions (Marshall, 1993). However, women are demonstrating a somewhat different managerial style than their male counterparts who predominate (Blackmore, 1989; Marshall, 1993). Helgesen (1995) depicted the new organization as a web in terms of both design and process, similar to a spider's web. The leader is at the central point and the filigree pattern reflects the relationships that exist, develop, change over time. Helgesen went further and called it a "web of inclusion," to mirror the process of its women leaders who "laboured continually to bring everyone at every point closer to the centre - to tighten ties, provide increased exposure, and encourage greater participation," (p. 20). Their web is one of openness and collegiality - sharing information, listening, incorporating others into decision-making and, ultimately, empowering others by redistributing the power throughout the organization. Women are observed as working cooperatively and collaboratively with others, building on the concept of the team, much more so than their male counterparts (Rosener, 1990; Rossler, 1992). As Lips (1991) notes, however, one's use of power and one's leadership style are interlinked. Accordingly, in my description of my activities as an Associate Dean within a university, my examples of power, used and 
perceived, will also be linked to my leadership style. The purpose here, though, is to focus on the concept of power and apply my experiences as an Associate Dean in a university to illustrate the evolving nature of power, albeit based on one self-reflective case study.

\section{RATIONALE}

My university, a mid-sized Canadian postsecondary institution which prides itself on being a national university, had, at the time of my tenure as Associate Dean, 263 women of a faculty of 1185 (or 22\%) (Employment Equity Census data, 1990). According to that same data base, two women (14\%) were classified as being in upper management positions (of a total of 14$) ; 16$ women $(14 \%)$ were considered to be in middle management positions (of a total of 114 positions). Then, 18 white women in total held the position of Associate Dean or higher. The largest group of women administrators was in the category of Associate Deans. Indeed, in 1990 when several hirings of women into middle-level management occurred, the university extolled its affirmative action stance and openly referred to 1990 as the "year of the [female] associate dean." Then as is now, women remained visibly under-represented within the university and accordingly, within the institution's decisionmaking structure, as were the other three federally-recognized under-represented groups: minority groups, persons with disabilities and Aboriginal peoples (Queen's Human Resources, 1990, 1997).

My Faculty, a faculty of education, reflected the gender disparity within the university as a whole. In the 1992-93 academic year, a majority of students were women ( $70 \%$ in total, consisting of $71 \%$ of students in the undergraduate education program and $67 \%$ of students in the graduate program). Our full-time faculty complement was 67 , of whom 12 or $18 \%$ were women. The infrastructure is Dean, Associate Dean, and seven Department Heads. I, as Associate Dean on a three-year term appointment, was the first woman to occupy this position in the faculty (no woman has ever been Dean); and one of the seven Department Heads was a woman. This synopsis reveals that, while $11 \%$ of the middlelevel and upper-level management of faculty were women, $18 \%$ of faculty and $70 \%$ of the entire student body were women. Women were indeed under-represented with the Faculty of Education.

One day, having received a telephone call from a parent, I realized just how little traditional power I had as Associate Dean. I was asked if 
I could use my power to make a special concession and accept his daughter into our Faculty as a student. When I informed him that I did not have that authority, the parent ended the conversation with a question that caused me to reflect on this whole issue of power, "What kind of power do you have?"

At that point, I realized that I did not have any real power over people, in the traditional sense. How did I see my role, then? And what types of power did I have? These questions pursued me, motivating me to investigate the topic. I grappled for a definition of power so that I could compare and perhaps contrast my experiences. Below is a review of the literature on power ending with several salient points. Then I will attempt to illustrate my experiences in light of each of the components in the power topology provided by Marshall (1984).

\section{DEFINING POWER}

Power has been studied from many different perspectives and disciplines over time (Hardy \& Clegg, 1996). Weber provided an early definition of power - "the possibility of imposing one's will upon the behaviour of other persons" (Weber as quoted in Abbott \& Carracheo, 1988 , p. 241). In the early years, power as well as organizational theory in general was studied predominately from a male perspective, i.e., only considering men as players within the institution (Marshall, 1993). Over time and as women's presence has been acknowledged within organizations, the concept of power seems to have become more inclusive. Accordingly, I offer an expanded definition of power which, I believe, reflects the emergent theory on power: "the ability to influence various outcomes" (Bowditch \& Buono, 1997, p. 192) by "mobiliz/ing] resources (human and material) to get things done" (Kanter, 1981, p. 104), "within a web of relations" (Burbules, 1986, p. 104).

Marshall (1984), studying power from a feminist perspective, developed a typology containing four dimensions or perspectives of power, which I believe below represents a synthesis on much of the literature on power. Her four dimensions of power are: power over others, structural factors which contribute to power, power generated through or with others, and personal power. Since then, the third factor (power generated through or with others) has been separated into two categories: power through others and power with others (Blase \& Walker, 1995; Wright \& Hersom, 1991). Another common name for power through others is 
facilitative power; and power with others has been termed as empowerment. All five dimensions of power are clarified below.

1. Power over others is the type of power that initially Weber described, reflecting the hierarchical nature of an organization. A person in a position of formal leadership had the legitimate right and the responsibility of dominating others in order to bring about the desired/intended outcome(s). Helgesen (1990) refers to this type of power as one traditionally used in organizations, and by men. The understanding here is that power is relational and asymmetrical.

French and Raven (1959) identified five possible bases of interpersonal power: reward power, coercive power, formal or positional or legitimate power, expert power, and referent or charismatic power. Lips (1991) points out that all these types of power are source-dependent, i.e., "their presence and strength depends on qualities the target person sees in or attributes to the person who is the source of the influence attempt" (p. 63). Subsequently, Raven (1965) identified a sixth power base and one that is not source-dependent: informational power. This is based on the content of the influence message rather than on the person delivering it. Of these six types of power, four would be consider this traditional form of power over others: reward power, coercive power, formal or positional or legitimate power, and informational power. As well, Marshall (1994) added still another descriptor to this type power: the ability to access organizational rewards (and punishments) for others.

This traditional concept of power, power over, is slowly being eroded in contemporary organizations (Bennis, 1997). Often, because of collective bargaining contracts and local and national laws governing employment, a manager, unilaterally, rarely has reward or coercive power. Through participative decision-making and the use of teams, resources are allocated and decisions are made. Moreover, the dependent person, the employee, is not powerless. Nyberg (1990) points out that a person, no matter how dependent, can exercise her or his own power by refusing to give consent or by laughing at a request or embarrassing the power-holder. Indeed, the following quote portrays the potential power of the alleged perceived powerless:

Even if one partner appears completely to dominate the other, the dependence remains reciprocal - no matter how absolute the right of life and death is held by masters over their slaves. 
Masters are dependent on their slaves' survival in order to retain lordship over them. (Crozier \& Thoenig, 1976, p. 562)

2. The component, the structural power factors, Marshall (1984) describes as power stemming from one's position in organization which influences another's/others' performance. Individuals may derive power by means of helping the organization handle uncertainty and risk, performing functions which are central to the organization's critical tasks or epitomizing the organization's ideal type of employee. The person has a high profile and is very visible within the organization. Kanter (1981) proposed a similar source of power; she contended that power was dependent on the position the person occupies in the organization - in order to access to resources, information and support or cooperation necessary to carry out the task.

3. Power through others has been termed facilitative power (Dunlap \& Goldman, 1991; Goldman, Dunlap, \& Conley, 1993). Goldman, Dunlap and Conley defined it as "the ability to help others achieve a set of ends that may be shared, negotiated, or complementary without being either identical or antithetical" (1993, p. 70). They articulated seven ways of demonstrating power through others:

(i) When arranging material resources that provide support for educational activities;

(ii) When selecting and managing people who can work together effectively (with respect to the mix of skills and personalities);

(iii) When supervising and monitoring activities for the purpose of feedback and reinforcement, and for making suggestions;

(iv) When providing networks for activities such as adding members to groups, linking groups to activities elsewhere, helping groups to "go public" with activities, and diffusing new ideas;

(v) When collecting and distributing information to allow greater control over the conditions of work and methods of teaching, and allowing a broader participation in decision-making;

(vi) When lobbying informally to cause movement toward goals, as opposed to exercising one's authority in the context of formal meetings; and

(vii) When serving as a role model of the organization's vision. 
According to Dunlap and Goldman (1991), facilitative power tends to develop increasingly in educational institutions in which faculty are of a more professional nature - such as the university. To quote them:

Facilitative power emphasizes the potential of maximizing problem-solving capabilities by incorporating more of the professional skills available in educational organizations. (pp. 25-26)

[Facilitative] power may primarily be an act of relationship between equals where acts of domination are the least desired alternatives. This does not reject authoritarian or hierarchical concepts of power, but suggests placing them in a broader context of power as that which facilitates the work of others. (p. 27)

Lips (1991) and Young et al. (1994) argue that power is gendered. Young et al. are critical of the description of facilitative power (see above), saying that the type of power is closely linked with personal power (see below) which is influenced by such variables as gender, race and age.

Another criticism comes from Wright and Hersom (1992). They attest that facilitative power merely reinforces the hierarchy rather than focussing on the individuals themselves. They said that facilitative power was "a concept that largely depends on the degree of consonance existing between the administrator's views and those of the followers" (p. 7). Their depiction of facilitative power reveals a somewhat benevolent form of the traditional form of power: power over others.

4. Power with others. This form of power has been referred to as "power to" (Sergiovanni, 1992), or "power together" (Blase \& Anderson, 1995) or "empowerment" (Sernak, 1995; Wright \& Hersom, 1992). Walker (1996) defines this form of power as "the capacity to act purposefully with the mobilization of the energies, resources, strengths or powers in each person through a mutual relationship" (p. 5). Marshall (1984) says that this form of power is essentially symmetrical, not asymmetrical, allowing for the possibility of actually creating power through relationships. To clarify, power is created because the membership of informal networks exchanges information, makes decisions and creates shared meanings. More examples of how power is developed through others are when people form liaisons to influence particular organizational issues; when one coaches another to foster an individual's growth and development; for 'social support' where an empathic relationship 
acts as a buffer against stress. Power resides in the relationship; it is not owned by any individual member. As Blase and Anderson (1995) expressed, "power is not so much transferred as it is released (my emphasis) through interpersonal transactions" (p. 28).

Walker (1996) elaborates on this form of power as having three dimensions: collaboration, caring and communication. Yet Sernak (1995) argues that "caring power" is another distinctive form of power. She states that empowerment continues to carry the notion of power, albeit sharing control or authority in a collaborative way, or by providing opportunities for others to develop. But, she says, empowerment does not reach the depth of relationship that caring does. It presumes power is still a commodity to be given away while implicitly assuming that the agent of power is better off for bestowing it. Rather, an ethic of caring presumes relationships; one sees situations in relation to others and makes decisions based on one's position within relationships.

Hurty's (1995) research with 17 women principals revealed five distinctive elements of power with others. They are described below:

1. Emotional energy - A willingness to use, honestly and openly, a full range of emotions in their work with teachers, students and the community. These women principals "act with another person in a way that acknowledges the personhood of the other, and shows sensitivity to the others' feelings" (p. 387).

2. Nurtured growth - These women principals believe that the primary emphasis in their work is the nurturance of children's growth (p. 388).

3. Reciprocal talk - defined as sensitive turn-taking in talking and listening (p. 390).

4. Pondered mutuality - which "involves turning things over in one's mind, exploring options, pondering responses garnered through reciprocal talk, checking back with colleagues, cogitating on possible consequences" (p. 391).

5. Collaborative change - which is "the art of defining common interests, common responsibilities, common problems and common solutions. It is also full participation in the development of those interests, the fulfillment of those responsibilities, and in problem-solving" (p. 394). 
Hurty concludes that "the vocabulary of connectedness symbolizes, perhaps most distinctly, the uniqueness of these women leaders' perspective on power" (1995, p. 395). Ferguson (1984), Marshall (1984), Blackmore (1989) and Adler, Laney, \& Packer (1993) all concur. Burbules (1986) describes power as a web or system of relations. Accordingly, this type of power is not restricted to women leaders; it just may be demonstrated more by them than by male leaders and has been more recently studied from this viewpoint.

5. Marshall's final type of power is that of personal power, referred to by Walker (1996) as "power within." French and Raven's (1959) remaining two types of power, charismatic and expert power, fall into this category of personal power. Marshall (1984) describes personal power as an individual's attributes which could include competence, courage, commitment, self-esteem, autonomy, stamina or resilience, flexibility to change, degree of integrity, and degree of self-control. Knoop (1992) also added the attributes of knowledge of self including knowing one's strengths and weaknesses, and degree of self-reflection. All these assumptions, attitudes and attributes form the basis of an individual's leadership identity (Walker, 1996). Interestingly, Adler, Laney and Packer (1993) found that all five women educational managers in their study seemed to be more comfortable in speaking about their own personal power rather than their professional power. The educators identified class, money, education, physical size, race as all contributing to their personal power. Adler, Laney and Packer (1993) commented that they were surprised that several of the women whom the researchers thought of as powerful did not, in fact, feel powerful and indeed mentioned their lack of power. Similarly, Miller and Cummins (1992) interviewed 125 women who reported that they defined power in terms of personal power (personal authority and control in themselves), but recognized that society looked upon power as power over others.

The literature review leading to this topology of power (see above) bears several summative comments. First, as Burbules (1986) pointed out, power is not only an individual possession, but it is relational and, accordingly, one which is socially constructed. Second, it is instrumental (Nyberg, 1981) in that is it "a means to an end" (p. 54) but it can also be a means of prevention (Burbules, 1986, p. 103). Third, power is partly psychological (Nyberg, 1981) in that it is inherent in the status quo of an organization (Burbules, 1986), not solely aimed at achieving 
particular intended outcomes as Nyberg $(1981,1990)$ proposed. Fourth, the power relations form a continuum within an organization: at one extreme is domination; at the opposite end is consent; and there exist a range of degrees of compliance in between (Burbules, 1986, p. 99). Fifth, a power relation may have several "types" which not necessarily distinctive, but rather interconnected or interdependent (Burbules, 1986; Young et al., 1994). Sixth, power can be considered as a "web of relations ... Power is not simply a matter of getting people to do things (or not do things), but a relation of human attitudes and activities against a background of conflicting interests" (Burbules, 1986, p. 104). Furthermore, the perception of that relationship may differ depending on the different players, their own attributes - ethnicity, gender, social class (Young et al., 1994) - and the situation (Adler, Laney, \& Packer, 1993; Knoop, 1992). Next, my own experiences as an Associate Dean will be explored using this five-part topology and the knowledge gained from this literature review on power

\section{AN ASSOCIATE DEAN EXPERIENCES POWER}

Comparing some of my experiences with the topology of power as uncovered in the literature review, I, as Associate Dean, initially believed that I had little power. In retrospect and overlaying the Marshall topology, I realized later that I was basing my conclusion solely on one type of power, the traditional concept of power over people.

1. Power over others. I now acknowledge that I had authority or legitimate power (French \& Raven, 1959), but no ability to reward or coerce my colleagues. Also access to rewards (and punitive measures) were outside of my realm but within that of the Dean, mainly in the form of merit pay. I would suggest, remind and advise others; I was the onsite administrator who communicated new or relevant university policy to faculty, students and staff (attributed to the absence of the Dean).

2. Structural power factors. I believe now that I had a considerable amount of structural power. I was very visible within our Faculty, and was the main person to consistently handle the barrage of new and different issues that university administrators addressed. Even though the Dean was absent quite a lot due in part to illness and in part to his travel schedule, at no time did he acknowledge that I was, in fact, Acting Dean in his absence. Despite this roadblock which I perceived impeded me as a manager, I enjoyed being confronted with and then solving or 
resolving problems and dilemmas. Ironically, one retiring colleague said that both my greatest strength and weakness was in my problem-solving ability; I tended to take on problems too quickly rather than working it through with the person who actually owned the problem. That feedback was well taken, and has not yet been forgotten. Another time, I intervened when a professor was intending to fail two students who submitted a joint rather than two individual assignments. I heard both versions, separately, and sought legal advice. I then informed the professor that if the students grieved his decision of failure, they would likely win. I continued that if he intend to pursue his decision to fail them, I would support both his decision and the consequences of that decision. The professor decided to pass the two students and asked how to avoid getting caught in this predicament again. I helped him to redraft his course outline incorporating within it some clearer direction regarding the assignments.

3. Power through others. Reflecting upon my work within the context of power and mapping my activities against the Goldman, Dunlap and Conley (1993) framework, I realized that I tried to enact facilitative power, power through others. I shall describe some of my actions in relation to each of the seven points in the framework. First of all, I think that what I did most of the time were tasks, both individually and as part of a group, which supported or enhanced the work of the faculty as a whole and, accordingly, the work of others. For example, when a new program component had been approved by faculty board, I coordinated the physical and human resources necessary in order to start that new aspect of the education program. Indeed, staffing the faculty's large education program was probably the greatest challenge of my position. I attempted to ensure that the needs of both the institution and the individual merged (i.e., trying to match what each professor wanted to teach with what s/he was good at teaching, and where was the greatest demand for her/him to teach).

Furthermore, since much of what I was charged to do could only be accomplished through committees and task forces, another important aspect of my work was centred around committees - striking committees made up of individuals who represented different interests but who could and would work together, and then monitoring those committees to ensure that the task was accomplished on schedule. As universities are filled with people who have much knowledge (often esoteric) and expertise and, consequently, people who are often strong-willed about their beliefs, determining the membership of committees was quite a challenging job in itself. 
Another aspect which I considered important in my position as Associate Dean was a two-part role as information processor and boundary-spanner. I was constantly seeking, sifting and giving out information to people inside and outside the Faculty. But I also had the responsibility of acquiring new information from outside and then disseminating that information to people in the faculty who should have it. While in many cases, this information was considered "nice to know" information for management, often that information was essential for certain members within the organization (Mintzberg, 1979). In the past, information had been used as a power source in some organizations where some boundary-spanners have been known to withhold information, either willfully or unintentionally (Pettigrew, 1972). I believe that, in that case, that selected use of information related to power over than through others. I felt, however, a large sense of responsibility not only to find out who should receive a particular piece of information, but also to ensure that those individuals did receive that information and as quickly as possible.

Another important aspect of my job, as I have defined it, is to act as a (self-imposed) monitor for equity within the faculty - to ensure that resources are allocated within the faculty in a fair and equitable manner, and that decisions are just. Dissatisfaction occurred, for example, when one faculty member perceived her/himself to be working harder, i.e., teaching more, than her or his colleagues; when one adjunct faculty member discovered that her/his teaching stipend was less than that of another adjunct; when a faculty member or student body perceived that another had been given a unilateral "perk." Surprising as it may seem, this last example was a relatively frequent occurrence.

Often I carried out my role in the background, playing what could be construed as almost a servant role (Greenleaf, 1977) to enable the faculty to carry out their work. And at other times, I was a lobbyist in ensuring that the Faculty's concerns were being addressed by senior management and others.

At all times, I believed myself to be a role model in our faculty. Especially being a woman in administration, I know that I was constantly being observed and my actions were scrutinized closely and criticized. Although as a woman I know that sometimes my words and opinions were rendered invisible (Lewis, 1993), $I$ was highly visible to all members of our organization - students, support staff and faculty. Finkelstein (1981) pointed out that the visible (few) women university 
administrators would be subject to pressure for exemplary performance, and that our failures would be generalized to all women. Through experience, I concur with her statement.

I believe that this type of power most clearly explains how most work is accomplished in a university. There, the sphere of power is restricted by limited term appointments and by the collegial nature of the organization. But power through others recognizes the quintessential nature of the university - a professional organization where faculty members are considered as more or less equals (although Caplan (1993) and others would disagree that women have achieved true equality throughout all ranks of the professorship), and where much of a faculty's or department's work is carried out by colleagues, individually and in the form of committees.

4. Power with others. It was very clear that the majority of my tasks depended upon the cooperation and consolidation of others. If faculty and staff would not or could not do the job, then either I would have to do it alone (if at all possible) or the job would go unfinished. Here, I believed, was a real test of my degree of power; several times in my tenure I realized that I was not being influential at all. I learned that I had to rely upon others and that there were tasks which I simply could not do alone. Consequently, I experienced how difficult it was at times to collaborate with others.

I also realized how important it was to truly understand one's colleagues - their strengths, their weaknesses, their likes, their dislikes, their philosophies, and even their methods of working with others. The better I know the people with whom I worked, the greater the success I believed $\mathrm{I}$ had in striking committees that could accomplish the task at hand and, at the same time, through committee work could help people develop. The strength of our professoriate, committees and organization as a whole resided in the synergy of the strength and competencies of each member of our Faculty.

In order to ensure that others had the correct and relevant information, I was challenged to ensure that there was clear and continuous communication. Now three years later, I appreciate the sustained use of e-mail in order to continually communicate and collaborate with people who are geographically separated.

Finally, I learned to appreciate both the formal networks within the organization and also the informal networks that I developed over time, and that I saw others using. These webs could be very supportive and 
very influential on their own. As Associate Dean, I relied on informal advice from the institutional lawyer, registrar, counsellors, human rights officer, and dozens of others who often had to connect with others before being able to provide any assistance. I often wondered how I could be effective in my position without using any of these links, both internal, but more often external.

5. Personal power. Interestingly, I too, like those women educators in Adler, Laney and Packer's (1993) study, feel most comfortable in this discussion of power when referring to my personal attributes which could be associated with power as opposed to how I exercise power. I hold a strong commitment to the teaching profession, to the Faculty and to the university as a whole. My expertise in project planning and in the annual scheduling of courses remains perhaps my strongest asset, one which was praised by my colleagues (perhaps for taking on tasks in which no-one else wished to participate). I tried to live my belief of being a visible manager within the facility. But often that front-line job as Associate Dean was gruelling and contentious. Accordingly, to regenerate, I used a time-management trick of booking an appointment with myself, thus building in some down time. I carried out my long-term habit of spending some time each day in self-reflection; I kept current a file ongoing of aspects of myself that required improvement. Often I felt that I was being challenged and sometimes even discriminated in the position by faculty, staff, students, potential students and their parents because of my gender; yet I am cogniscent of the fact that I am in a privileged position because I am white.

\section{SOME REFLECTIONS}

After having put my experiences into the context of the Marshall (1984) topology, I came to some conclusions, partly conclusions about myself. One, power as a evolving concept is quite complex and can be viewed from many different perspectives. Two, prior to this analysis, I had perceived power only in its traditional form - as power over people. Three, as Associate Dean, I realized that I had been focussing more on "having power," instead of on the use or exercise of the power of my position, in my attempts to carry out certain plans within the organization. Four, I recognize now that the traditional form of power does not and cannot work in this university setting. University managers do not have the resources to use force or fear on the academic community; and the 
wealth of knowledge within the academe reduces the probability of getting away with using false or biased information as a strategy to influence others. Five, I can now accept the discomfort I have felt and what Aisenberg and Harrington (1986) referred to when I have exercised power in its traditional form. And finally, by studying power, I learned that not only do I have the right to exercise power but I have the responsibility to do so in my position as Associate Dean.

\section{CONCLUSIONS}

These ruminations have led me to an answer to the question "What kind of power do I have?" I truly believe that I had facilitative power as defined by Dunlap and Goldman (1991) and elaborated upon by Goldman, Dunlap and Conley (1993). I worked to support and encourage the work of others, and I worked most often through groups of people in the form of committees - both standing committees, the formal committees established within the faculty structure, and ad-hoc committees, committees that often are established in order to carry out the work of the faculty. My "power" was not over people; rather my "power" was enabling people and resources together in such a way to enhance the main activities of the faculty - power through people.

To expand upon the analogy that Helgesen (1995) developed, I too saw myself at the centre of the "web of inclusion" - similar to the one that Charlotte weaves - connecting people with people, connecting information with people, and connecting people with the physical resources to accomplish the tasks at hand. I facilitated the connection both directly and indirectly, and ensured that the allocations are being assigned in a fair and equitable manner.

I agree with Wright and Hersom that facilitative power "largely depends on the degree of consonance existing between the administrator's views and those of the followers" (p. 7). Yet I argue that the responsibility rests with the manager to be aware of, work within, and sometimes to reconcile those differing perspectives. Furthermore, I believe that my degree of success lay in my use of facilitative power working through others to accomplish the tasks at hand. I acknowledge, however, that the real work of our as in any organization is done through people, the faculty and staff, themselves. In that respect, the concept of power through others exemplifying one's leadership style is reinforced. The more the members of the university community (and indeed any 
social structure) feel empowered, then the more they should act empowered (Bennis, 1997).

But I agree also with Wright and Hersom (1992) that we have moved from viewing power in its traditional form, and that we should be moving toward a state of power with others or empowerment. Just as Toffler's third wave (1980) was built upon the other two previous waves, power with others appears also to be a product of power over and then power through others.

I do believe that to truly realize this form of power however, more matching should occur within the university. My future scenario of power with others in postsecondary institutions is that university faculty would be recruited and selected based not only upon their expertise in their own discipline, but also upon their ability to collaborate and work effectively with others. Joint research and teaching activities would be much more widespread. The individuals in the formal positions of authority would have specific managerial tasks to accomplish, acting more as an orchestra conductor does - to bring out the best of each person within the larger group setting. Finally, the core attributes of power with others lies in collaborating, caring and communicating.

\section{LOOKING AHEAD}

As people in organizations constantly interact, they form different types of web-like relationships (Helgesen, 1995). Each relationship is based on people and a plan - and the plan usually includes both the means and the end (i.e., both how to carry out the task and what should be accomplished at the outset). One management objective is to attain the consent of the other people in the relationship about both the process and the product. A desired goal is to have consent based upon a balanced and mutual trust, with all members of the community feeling empowered rather than powerless, and included rather than excluded, ignored or silenced.

But how can we women, as one of the under-represented groups in academe move toward this state of empowerment? Since our status was "socially created," Epstein (1988) believes that it can also be "socially altered" (p. 231). Some strategies for women to continue the movement from a dependent status to an empowered one within the university as suggested by Acker and Piper (1984), Aisenberg and Harrington (1986), Caplan (1993), Chamberlain (1988), Epstein and Coser (1981) and 
Rendel (1984) are: publish in refereed journals, be part of and use networks, find and use a mentor, exert political pressure for legislation on employment equity, be part of development training programs, and encourage the establishment of and reliance on talent pools.

Power is inherent in social life, as Nyberg (1981) has pointed out. Its omnipresence demands that women of the academe must not only learn about power but also, and perhaps more importantly, learn to manage power, despite its different perceptions by women in positions of leadership.

\section{References}

Abbott, M.S., \& Caracheo, F. (1988). Power, authority, and bureaucracy. In N.J. Boyan (ed.), Handbook of research on educational administration, (pp. 229-258). White Plains, NY: Longman.

Acker, S., \& Piper, D.W. (1984). Is higher education fair to women? Worcester, UK: Billing \& Sons Ltd.

Adler, S., Laney, J., \& Packer, M. (1993). Managing women. Buckingham: Open University.

Aisenberg, N., \& Harrington, M. (1986). Women of academe: Outsiders in the sacred grove. Amherst, MA: University of Massachusetts Press.

Bennis, W. (1997). Managing people is like herding cats. Provo, UT: Executive Excellent Publishing.

Blackmore, J. (1989). Educational leadership: A Feminist critique and reconstruction. In J.H. Smyth, (ed.), Critical perspectives on educational leadership, (pp. 93-130). London: Falmer Press.

Blase, J. \& Anderson, G.L. (1995). The micropolitics of educational leadership: From control to empowerment. London: Cassell.

Bowditch, J.L., \& Buono, A.F. (1997). A primer on organizational theory, (4th ed.). Toronto, ON: J. Wiley \& Sons.

Burbules, N.C. (1986). A theory of power in education. Educational Theory, $36(2), 95-114$

Canadian Education Association. (1996). Ki-es-ki handbook. Toronto, ON.

Caplan, P.J. (1993). Lifting a ton of feathers: A women's guide for surviving in the academic world. Toronto, ON: University of Toronto Press.

Chamberlain, M.K. (Ed.). (1988). Women in academe: Progress and prospects. New York, NY: Russell Sage Foundation.

Crozier, M., \& Thoenig, J. (1976). The regulation of complex organized systems. Administrative Science Quarterly, 21(4), 547-569 
Dunlap, D.M., \& Goldman, P. (1991). Rethinking power in schools. Educational Administration Quarterly, 27(1), 5-29.

Epstein, C.F. (1988). Deceptive distinctions: Sex, gender, and the social order. New York, NY: Russell Sage Foundation.

Epstein, C.F. (1971). Women and the professions. In C.F. Epstein \& W.J. Goode, (eds.), The other half: Roads to women's equality, (pp. 122-129). Englewood Cliffs, NJ: Prentice Hall.

Epstein, C.F., \& Coser, R.L. (Eds.). (1981). Access to power: Cross-national studies of women and elites. London: George Allen \& Unwin.

Ferguson, K.E. (1984). The feminist case against bureaucracy. Philadelphia, PA: Temple.

Finkelstein, C.A. (1981). Women managers: Career patterns and changes in the United States. In C.F. Epstein \& R.L. Coser, (eds.), Access to power: Cross-national studies of women and elites, (ch. 13). London: George Allen \& Unwin.

French, J.R.P., Jr., \& Raven, B. (1959). The basis of social power. In D. Cartwright, (ed.), Studies in social power. Ann Arbor, MI: University of Michigan.

Goldman, P., Dunlap, D.M., \& Conley, D.T. (1993). Facilitative power and nonstandardized solutions to school site restructuring. Educational Administration Quarterly, 29(1), 69-92.

Greenleaf, R.K. (1977). Slavery leadership: A journey into the nature of legitimate power and greatness. New York, NY: Paulist Press.

Hardy, C., \& Clegg, S.T. (1996). Some dare call it power. In S.R. Clegg, C. Hardy \& W.R. Nord, (eds.), Handbook of organization studies, (pp. 622-641). Thousand Oaks, CA: Sage.

Helgesen, S. (1995). The web of inclusion. New York, NY: Doubleday.

Hurty, K. 1995). Women principals - leading with power. In D. Dunlap \&

P. Schmuck, (eds.), Women leading in education, (pp. 380-406). New York, NY: SUNY Press.

Kanter, R.M. (1981). Power failure in management circuits. Harvard Business Review, No. 12191, 103-113.

Kanter, R.M. (1977). Men and women of the corporation. New York, NY: Basic Books.

Knoop, R. (1992). Power tactics. Education Canada, 32(1), 15-19.

Lewis, M. (1993). Without a word: Teaching beyond women's silence. New York, NY: Routledge.

Lips, H.M. (1991). Women, men and power. Mountain View, CA: Mayfield.

Marshall, C. (1993). The new politics of race and gender. Washington, DC: Falmer Press.

Marshall, J. (1984). Women managers: Travellers in a male world. Toronto, ON: Wiley. 
Millers, C.L., \& Cummins, A.G. (1992). An examination of women's perspectives on power. Psychology of Women's Quarterly, 16, 415-428.

Mintzberg, H. (1979). The structuring of organizations. Englewood Cliffs, NJ: Prentice-Hall.

Nyberg, D.A. (1981). Power over power. Ithaca, NY: Cornell University Press.

Nyberg, D.A. (1990). Power, empowerment, and educational authority. In S.L. Jacobson \& J.A. Conway, (eds.), Educational leadership in an age of reform, (pp. 47-64). New York, NY: Longman.

Pettigrew, A.M (1972). Information control as a power resource. American Journal of Sociology, 6, 187-204.

Raven, B. (1965). Social influence and power. In I.D. Steiner \& M. Fishbein (eds.). Current studies in social psychology. New York: Holt, Rinehart \& Winston.

Rees, R. (1990). Women and men in education. A national survey of gender distribution in school systems. Toronto, ON: Canadian Education Association.

Rendel, M. (1984). Women academics in the seventies. In S. Acker \& D.W. Piper (eds.), Is higher education fair to women? (pp. 163-179). Worcester, UK: Billing \& Sons Ltd.

Rossler, L. (1992). Androgyny: An emerging perspective on leadership. The Canadian School Executive, 1/(9), 11-14.

Rosener, J. (1990). Ways women lead. Harvard Business Review, (NovemberDecember), 119-125.

Sergiovanni, T.J. (1992). Moral leadership: Getting to the heart of school improvement. San Francisco, CA: Jossey-Bass.

Sernak K.S. (1995). Conceptualizing an ethic of caring within bureaucracy: $A$ study of leadership. Paper presented at the America Education Research Association conference in San Francisco, CA.

Statistics Canada. (1992). A statistical portrait of elementary and secondary education in Canada. Ottawa, ON.

Toffler, A. (1980). The third wave. New York, NY: Bantam Books.

Walker, L.J.S. (1996). Making a difference through generative leadership. Paper presented at the Senior Women Academic Administrators of Canada annual conference in Winnipeg, MB.

Wright, R., \& Hersom, N. (1992). A novel perspective on power in organizations. Paper presented at the Canadian Society for the Study of Education conference, in June 1992 at Charlottetown, PEI.

Young, B., Chovanec, D., \& Scott, S. (1994). Joining the voices of learners. A paper prepared for presentation in the symposium Organizing for Learning at the American Education Research Association conference in New Orleans, LA. 